\title{
Breast Carcinoma with Osteoclastic Giant Cells
}

National Cancer Institute

\section{Source}

National Cancer Institute. Breast Carcinoma with Osteoclastic Giant Cells. NCI

Thesaurus. Code C40349.

An invasive breast adenocarcinoma characterised by the presence of non-neoplastic stromal osteoclastic giant cells. The carcinomatous component is usually an invasive ductal carcinoma, although all other breast adenocarcinoma subtypes have also been described. The prognosis depends on the characteristics of the adenocarcinomatous component, and is not related to the presence of the giant cells. 